\title{
Enhanced buoyancy and hence upwelling of subsurface Kuroshio waters after a typhoon in the southern East China Sea
}

\author{
Chen-Tung Arthur Chen ${ }^{\mathrm{a}, *, 1}$, Cho-Teng Liu ${ }^{\mathrm{b}}$, W.S. Chuang ${ }^{\mathrm{b}}$, Y.J. Yang ${ }^{\mathrm{c}}$, \\ Fuh-Kwo Shiah $^{\mathrm{b}}$, T.Y. Tang ${ }^{\mathrm{b}}$, S.W. Chung ${ }^{\mathrm{b}}$ \\ a Institute of Marine Geology and Chemistry, National Sun Yat-sen University, Kaohsiung 804, Taiwan, ROC \\ ${ }^{\mathrm{b}}$ Institute of Oceanography, National Taiwan University, Taipei 100, Taiwan, ROC \\ ${ }^{\mathrm{c}}$ Department of Marine Science, Chinese Naval Academy, P.O. Box 90175, Tsoying, Kaohsiung, Taiwan, ROC
}

Received 14 March 2002; accepted 27 February 2003

\begin{abstract}
Much has been documented worldwide on the implications of the passage of a tropical cyclone on a shelf ecosystem. In particular, wind mixing, resuspension and increased terrestrial runoff have thus far been pinpointed as the three major processes that bring about higher depth-integrated values of nutrients, chlorophyll $a$, primary and bacterial production, particulate organic carbon and nitrogen concentrations as well as biomass in the water column. Here, however, there is evidence to indicate that the cross-shelf upwelling of nutrient-rich subsurface Kuroshio water likely increased significantly after the passage of typhoon Herb in a normally downwelling region northwest of Taiwan. This phenomenon, most probably due to an enhanced buoyancy effect resulting from excessive rainfall, offers the best explanation for the lower temperatures yet higher salinity and larger amounts of nutrients that were observed in the deep and bottom coastal waters after the typhoon in July 1996. Further, there are indications that the episodic event might have pushed the Kuroshio towards the shelf-break, which then facilitated the onshore transport of subsurface Kuroshio waters. These new sources of nutrients along with nutrients brought in by the increased terrestrial runoff would eventually mix in or upwell to the euphotic zone on the shelf, thereby supporting new production.
\end{abstract}

(C) 2003 Elsevier Science B.V. All rights reserved.

Keywords: Buoyancy; East China Sea; Typhoon; Kuroshio; Upwelling; Productivity

\section{Introduction}

As a rule, biogeochemical processes principally occur in the upper $200 \mathrm{~m}$ of the sea and are often associated with continental margins. Although conti-

\footnotetext{
* Corresponding author. Fax: +886-7-525-5346.

E-mail address: ctchen@mail.nsysu.edu.tw (C.-T.A. Chen).

${ }^{1}$ All co-authors contributed equally to this paper.
}

nental margins, with waters shallower than $200 \mathrm{~m}$ occupy a mere $7 \%$ of the total ocean surface and even less than $0.5 \%$ of the total ocean volume, they still play a major role in oceanic biogeochemical cycling (Chen et al., 1994; Hall et al., 1996; Wong et al., 2000). In fact, even significantly higher rates of organic productivity occur in the coastal oceans than in the open oceans because of rapid turnover and the higher supply of nutrients from upwelling and riverine 
inputs. To illustrate this, $8-30$ times more organic carbon and 4-15 times more calcium carbonate per unit area, for example, accumulate in the coastal oceans than in the open oceans. Similarly, gas exchange fluxes of carbon and nitrogen are considerably higher in coastal waters than in the open oceans per unit area. As a result, it has been reported that around $14 \%$ of total global ocean production along with $80-90 \%$ of new production, and as much as up to $50 \%$ of denitrification take place in the coastal oceans. Also located here are the burial sites of $80 \%$ of the organic carbon derived from both oceanic processes and terrestrial sources and more than $50 \%$ of present-day global carbonate deposition (Biscaye et al., 1994; Liu et al., 2000; Chen et al., 2003). New production, net denitrification and the burial of organic carbon, of course, all require external sources of nutrients.

Not only are shelf systems very dynamic but they also show large spatial and temporal variability. Because of their shallow depth, continental shelves are particularly affected by episodic events, such as tropical cyclones or typhoons and hurricanes. The effects of these on shelf waters have been documented extensively over the past 40 years, but such research has mainly described the relationship between wind and flow patterns (e.g. Chew et al., 1962; Murray, 1970; Smith, 1982; McLeish et al., 1997). The effects on shelf ecosystems have been neglected until only recently. It is expected that in many shallow (i.e. bottom depth $<200 \mathrm{~m}$ ) aquatic ecosystems, physical disturbances resulting from hurricanes or typhoons may cause subsequent changes with regard to chemical properties, which in turn affects biological productivity (Furnas, 1989; Ritzrau and Graf, 1992; Chang et al., 1996; Dickey et al., 1998a,b; Jickells, 1998). Gilbes et al. (2001) also reported that nutrients delivered to the coastal waters increased significantly after a hurricane because of enhanced land runoff. They went on to state that "This pulse of nutrients to the coastal waters significantly increased phytoplankton concentrations."

In late July 1996, two strong typhoons (Gloria and Herb) swept through Taiwan, one after the other. This opportunity was taken to watch for any short-term temporal variations in chemical and biological parameters after the passage of these two typhoons (Shiah et al., 2000). In that study, a transect with four sampling stations was visited twice in 1996 and 1997, but only once in 1994. Data collected in 1994 and 1997 indicate that the study area is a typical oligotrophic system when there are no typhoon disturbances. However, after the passage of the cyclonic events of 1996, all of the measured values of the chemical and biological parameters were much greater than those observed during normal summer periods (1994 and 1997). The depth $(40 \mathrm{~m})$ integrated values of chlorophyll $a$ (Chl. a), nitrate $\left(\mathrm{NO}_{3}\right)$ and particulate nitrogen (PN) concentrations increased $18 \%, 169 \%$ and $73 \%$, respectively. More significantly, primary production, particulate organic carbon (POC) concentrations and bacterial production as well as biomass at least doubled.

Just like Gilbes et al. (2001), Shiah et al. (2000) recognized the effects of terrestrial runoff, and they also identified wind mixing and resuspension brought about by the typhoon as the major factors responsible for these enhanced concentrations and production. It is the purpose of this paper to show that, in addition to these factors, the upwelling of subsurface Kuroshio water was also enhanced after the passage of typhoon Herb, perhaps because of a larger buoyancy effect caused by the rains as well as the shoreward movement of the Kuroshio caused by the typhoons. There are grounds to believe that the cross-shelf upwelling is even potentially a much more important source of external supply of nutrients than terrestrial runoff.

\section{Study area}

Data were collected from three cruises conducted on the same transect on the northeastern continental shelf (bottom depth ca. 70-100 m) of the Taiwan Strait (Fig. 1) during the 1994, 1996 and 1997 summer seasons. Overlapping on Fig. 1 is the typical nitrate distribution of surface waters around the study area (Gu, 1991; Wang, 1991). The transect is not far from a major upwelling center located off the northeastern corner of Taiwan (as shown by the circle) where subsurface Kuroshio waters with an elevated nitrate concentration are known to upwell even to the surface year-round (Gong et al., 1992, 1996). Even though station 1 is located just off the 


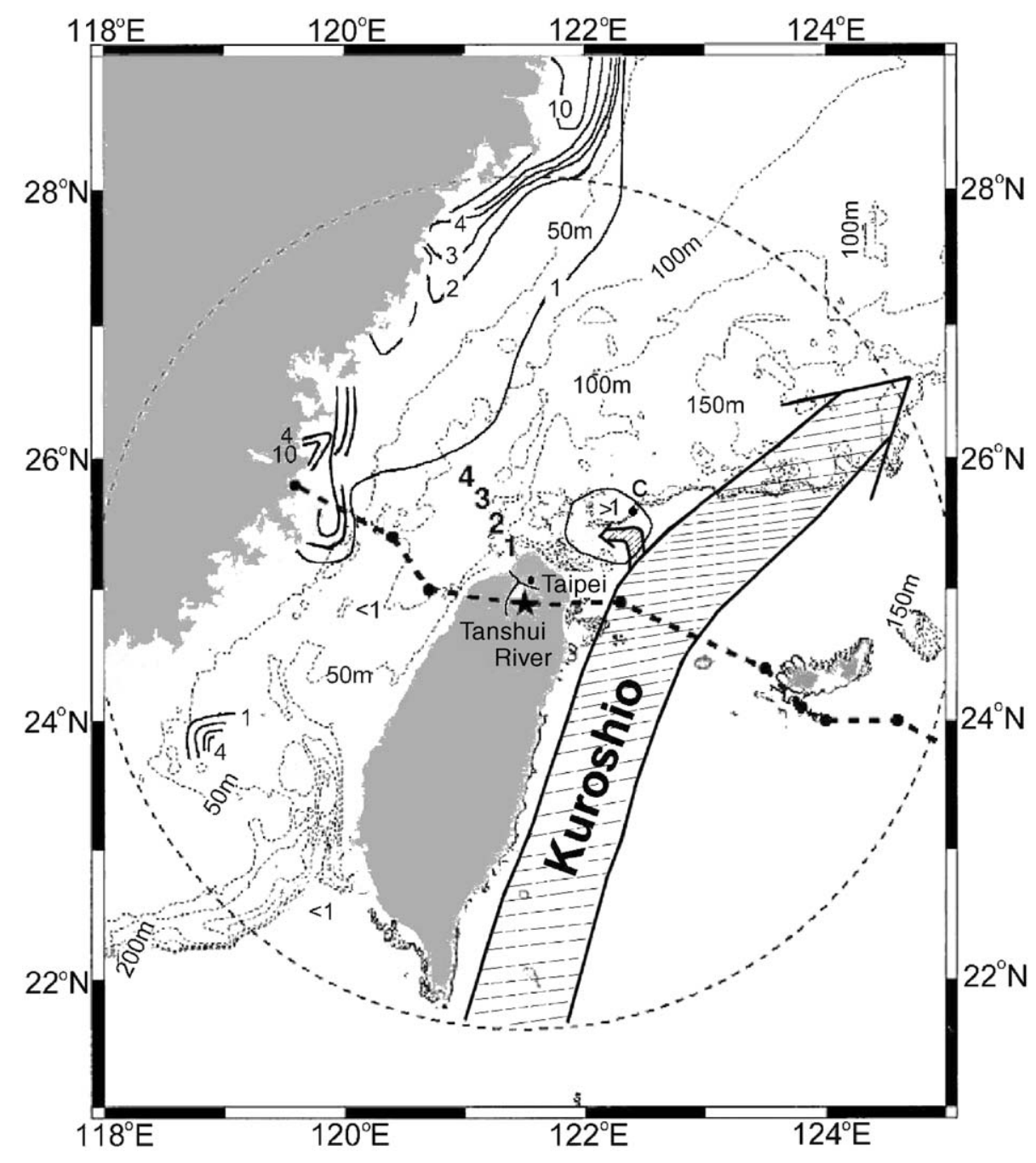

Fig. 1. Map of the Taiwan Strait showing sampling stations. The bold dotted line and the star symbol indicate, respectively, the pathway of typhoon Herb and its central position at 2300 on July 31, 1996 (data source: The Central Weather Bureau, Taiwan). Dashed lines indicate

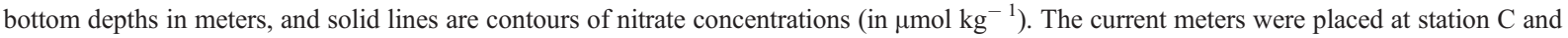
near station 4.

Tansui River estuary, the surface water is still normally low in nitrate.

The 1996 cruise (Shiah et al., 2000) was conducted 4 days after typhoon Herb (wind speed up to $53 \mathrm{~m}$ $\mathrm{s}^{-1}$ ) had swept through northern Taiwan (Fig. 1; July 29-31, 1996). The four sampling stations were visited twice (Cruises 96-1 and 96-2 in Fig. 2) with an interval of $43.47 \mathrm{~h}$, to represent the opposite phase of an $M_{2}$ tidal cycle. For the purposes of comparison, the 1994 and 1997 cruises represented normal summer conditions when southwest monsoons usually prevail, but there had been no typhoons within 1 month prior to those cruises. On the 1994 cruise, sampling was performed only once at each station, but on the 1997 cruise, each station was visited twice, again with an interval of $43.47 \mathrm{~h}$ (Cruises $97-1$ and 97-2 in Fig. 2). For simplicity, 94 denotes the 1994 cruise, 96-1 and 96-2 stand for the 1996 cruises while 97-1 and 97-2 stand for the 1997 cruises. Details as to sampling and measurements are given in Shiah et al. (2000) and are 
(a) Temperature $\left({ }^{\circ} \mathrm{C}\right)$
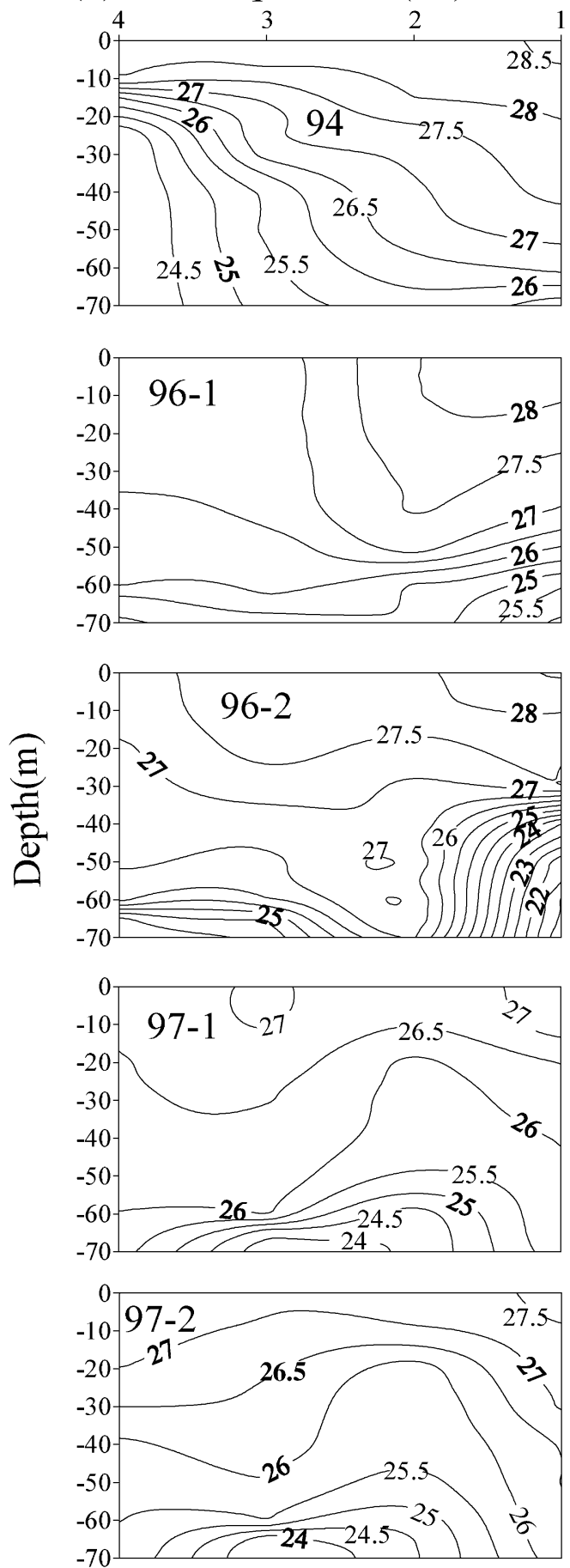

(b)
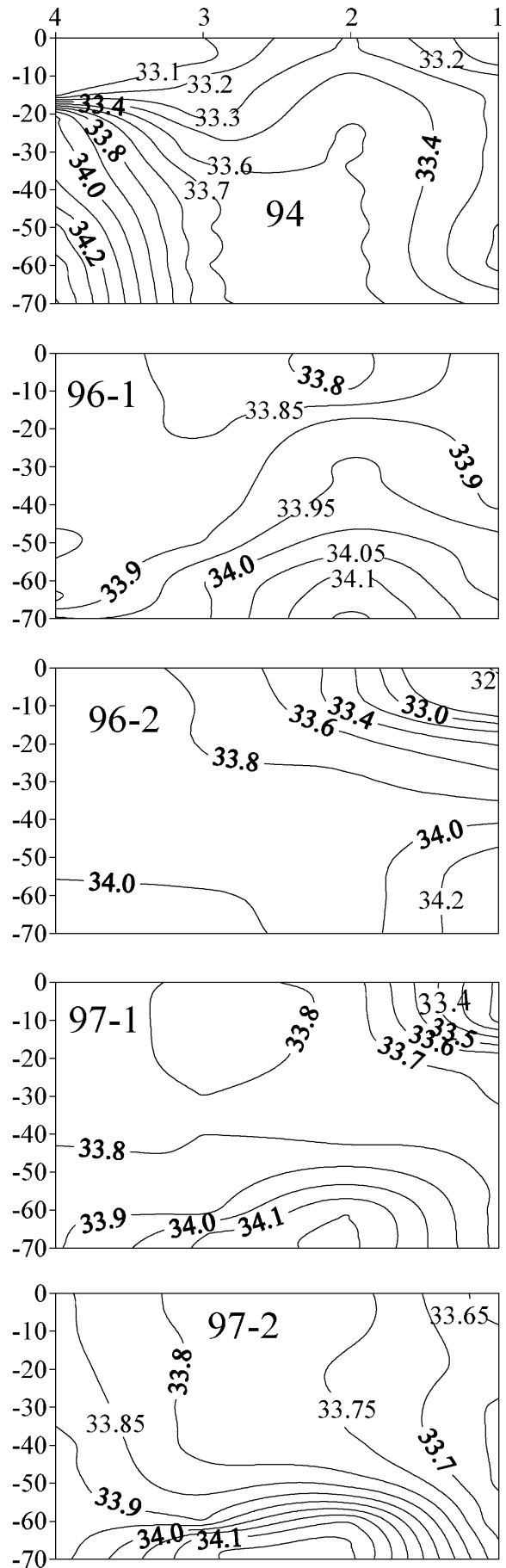

Fig. 2. Cross-sections of temperature (a), salinity (b), $\sigma_{\mathrm{t}}(\mathrm{c})$, nitrate (d), chlorophyll $a(\mathrm{e})$; particulate organic carbon (f), particulate nitrogen (g) and PON/PN ratio (h) derived from non-typhoon $(94,97-1,97-2)$ and typhoon $(96-1,96-2)$ periods. The 96-2 and 97-2 cruises, respectively, lag the $96-1$ and $97-1$ cruises by $43.74 \mathrm{~h}$. 


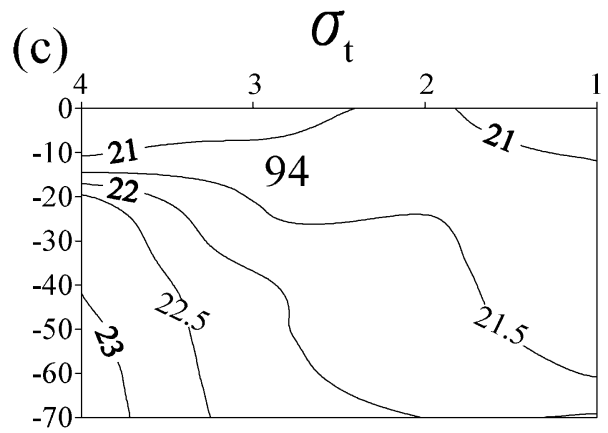

(d) $\quad \mathrm{NO}_{3}(\mu \mathrm{M})$
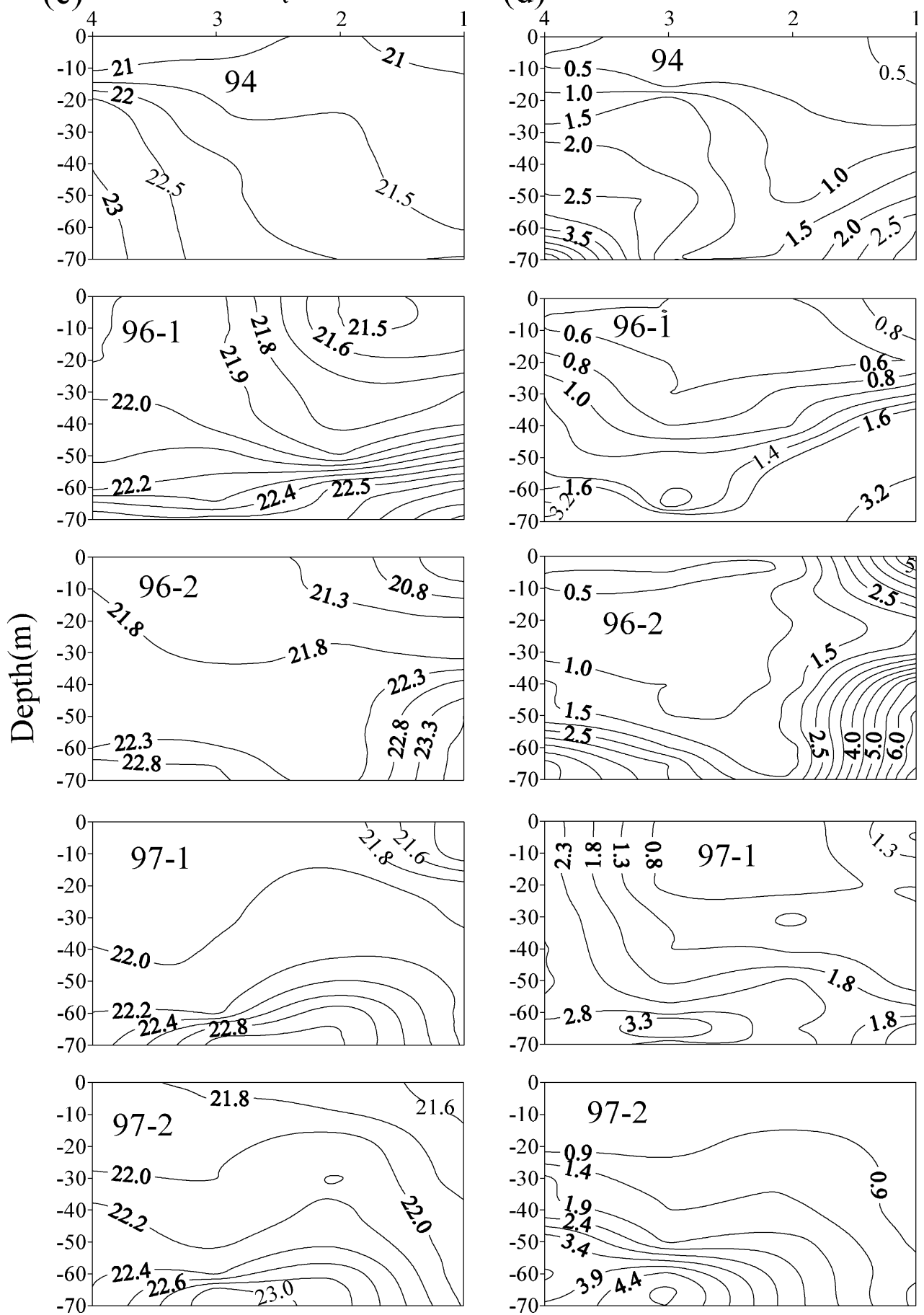

Fig. 2 (continued). 
(e) Chlorophyl1-a $\left(\mathrm{mg} \mathrm{m}^{-3}\right)$
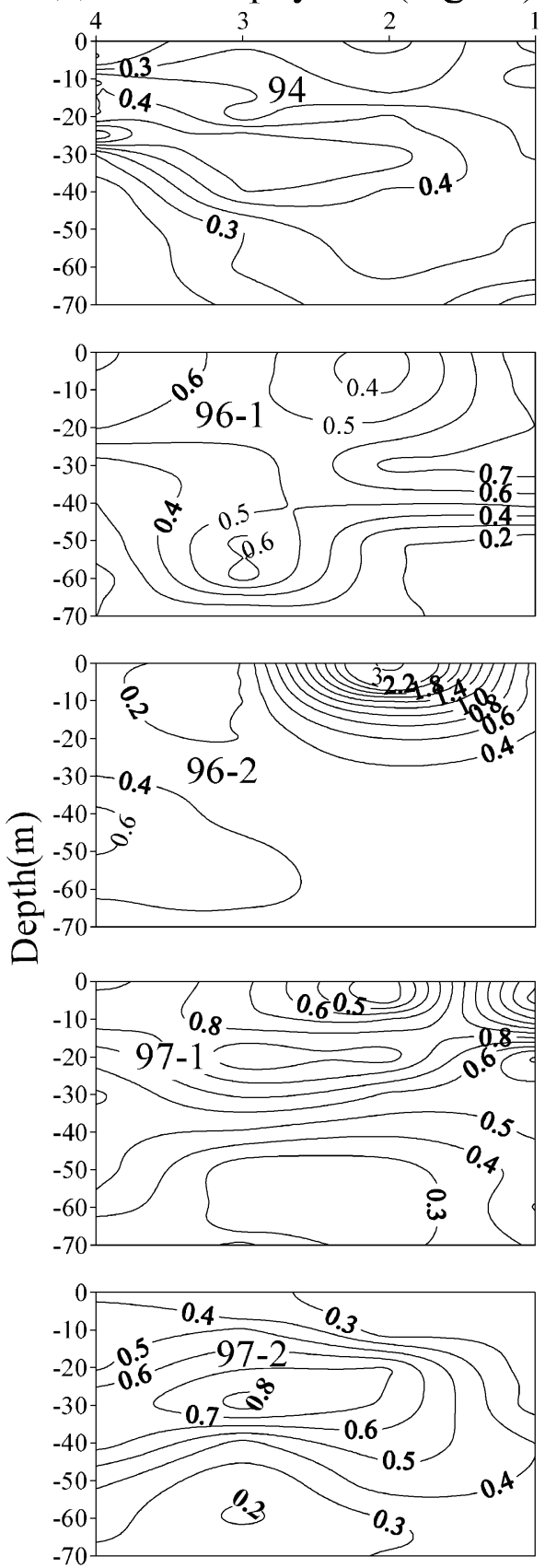
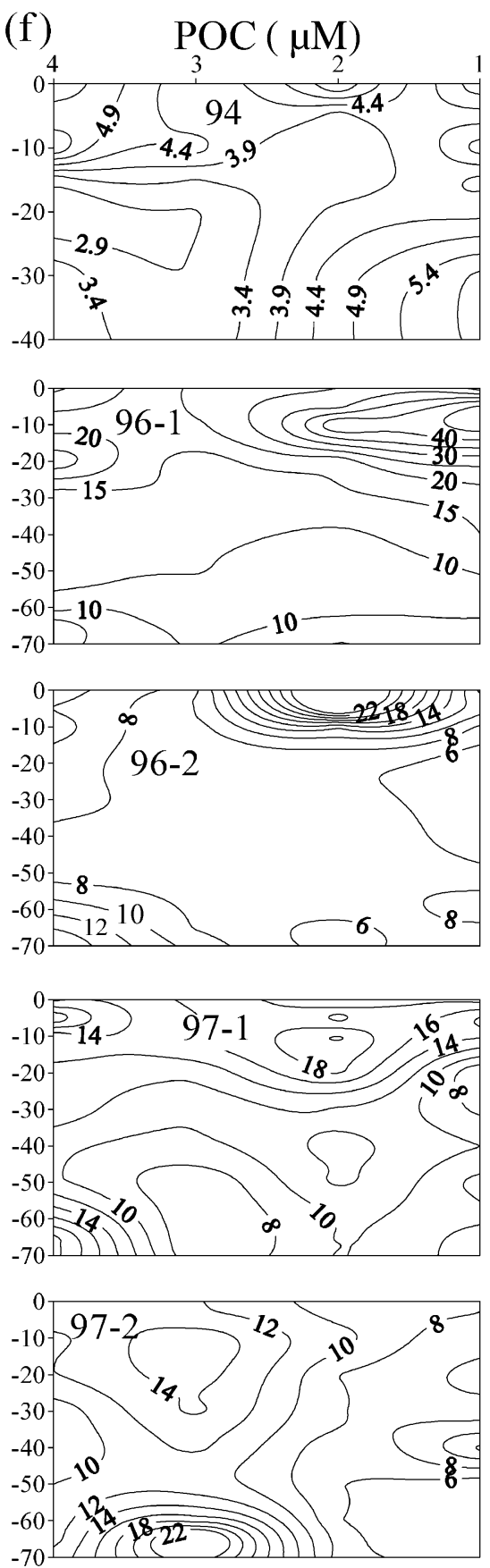

Fig. 2 (continued). 
(g)
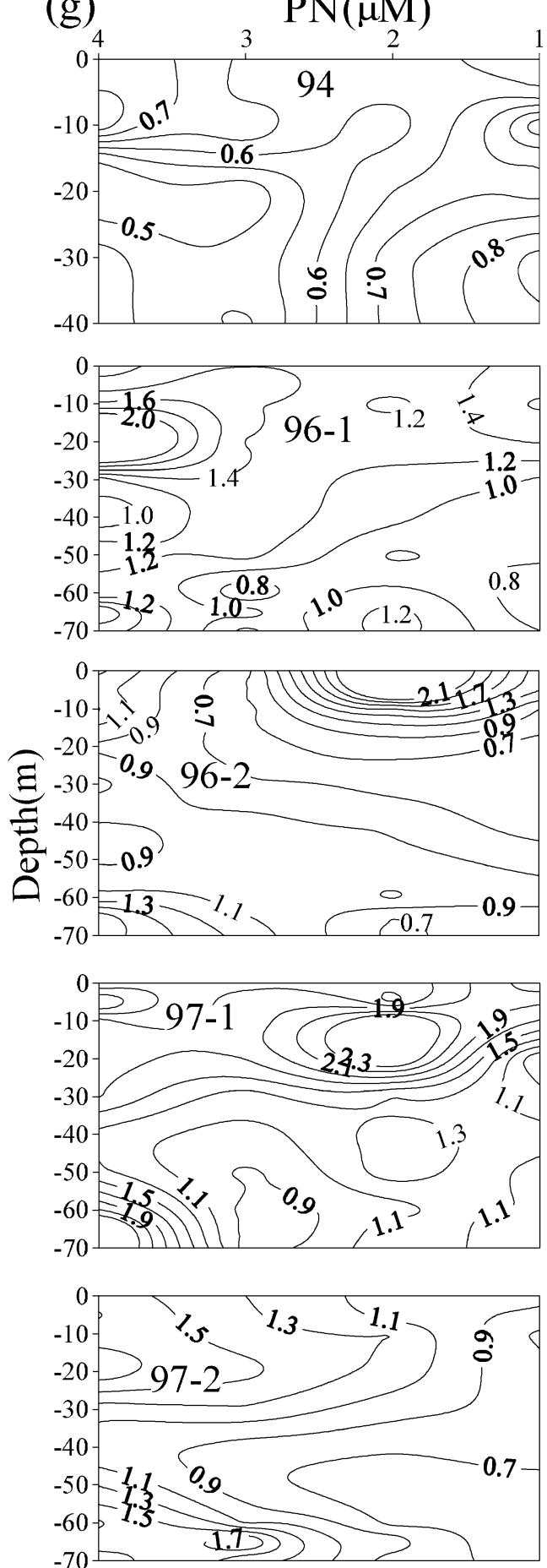

(h)
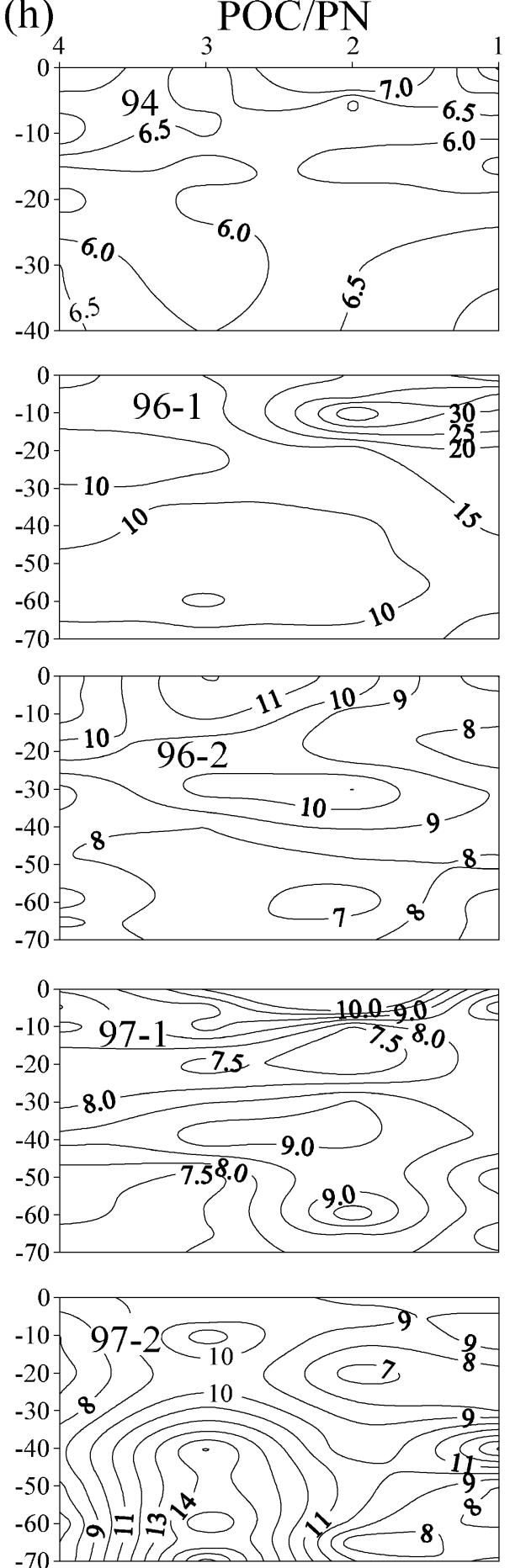

Fig. 2 (continued). 
therefore not repeated here. A bottom-mounted ADCP (RD Instrument Workhorse ADCP $300 \mathrm{kHz}$ ) was placed near station 4 between August 1 and October 15, 2002.

\section{Results}

Fig. 2 depicts parts of the contours of the measured variables collected from the non-typhoon (94, 97-1 and 97-2) and the typhoon (96-1 and 96-2) periods. The individual values of the measured variables derived from the 1997 cruise were very similar to those of 1994, both in terms of temporal and spatial variability. The depths of the mixed layer of each of 94, 97-1 and 97-2 are shallow (15-20 m; Fig. 2a) with a well-defined thermocline. In contrast, after the typhoon (96-1), the magnitude of temperature stratification in the upper layer seems to have been much weaker perhaps due to the effects of strong wind mixing. Two days later, however, the temperature stratification strengthened (Fig. 2a, 96-2) because a thin layer of much fresher water then covered the surface at that time (Fig. 2b, 96-2). It is particularly noteworthy that a few days after the typhoon, more saline water (Fig. 2b, 96-2 lower right-hand corner) at a temperature a full $4{ }^{\circ} \mathrm{C}$ colder (Fig. 2a, 96-2) entered the deep layer at St. 1 which is closest to the coast. This is the first indication that colder, but saltier and denser subsurface Kuroshio water (Chen et al., 1995) appeared (Fig. 2a-c). Further, although the low salinity ( $<32.0$; Fig. 2b) but high nitrate (Fig. 2d) surface water observed at St. 1 of 96-2 indicates the influence of land runoff, another indication of the intrusion of the nutrient-rich subsurface Kuroshio water is the very high nitrate value near bottom at St. 1 (Fig. 2d).

Chlorophyll $a$ concentrations both under normal summer conditions and during 96-1 were low (below
$1 \mathrm{mg}$ Chl. $a \mathrm{~m}^{-3}$ ) with a subsurface maximum located at ca. 10-25 m (Fig. 2e). In the case of 962 , however, the highest value (3.0 mg Chl $a \mathrm{~m}^{-3}$ ) occurred at the surface while all other values of Chl. $a$ decreased with depth, with no perceptible subsurface maximum. The profiles of primary production (PP) derived from the 94 and 96-2 cruises revealed the same trend with the highest values appearing near the surface, but then decreasing with the depth. They were, on the other hand, much higher after the typhoon (Shiah et al., 2000). The depth-integrated (to $40 \mathrm{~m}$ ) primary and bacterial productivities are given in Table 1. The highest values were found during 96-2, but even during 96-1, they were still a factor of 5 to 10 times higher than during normal years.

The POC and PN values showed dramatic differences on these three cruises. During the non-typhoon period, POC reached only $6 \mu \mathrm{M}$ during 94 and $18 \mathrm{mM}$ during 97-1 and 97-2 (Fig. 2f). After the typhoon, however, most of the POC values were higher than 7 $\mathrm{mM}$ with a maximum of over $40 \mathrm{mM}$ (Fig. 2f; 96-1, 96-2). Similarly, the PN values were at their highest near surface during the typhoon period (Fig. $2 \mathrm{~g}$ ). The $\mathrm{POC} / \mathrm{PN}$ molar ratios derived from all cruises were quite constant at all stations (Fig. 2h), and were consistent with the Redfield $\mathrm{C} / \mathrm{N}$ ratios found in the ECS (Chen et al., 1996). Some ratios derived from 961 , nevertheless, did reach 40 .

\section{Discussion}

The enhancement of chemical variables (i.e. $\mathrm{NO}_{3}^{-}$, POC and PN) after the typhoon was interpreted by Shiah et al. (2000) as the result of the effects of either wind mixing or terrestrial inputs or both. They also reported that in areas remote from the coast, subsurface waters rich in inorganic nutrients might have

Table 1

Depth-integrated (to $40 \mathrm{~m}$ ) primary and bacterial productivities

\begin{tabular}{|c|c|c|c|c|c|c|c|c|c|c|}
\hline \multirow{2}{*}{$\frac{\text { Station }}{\text { Cruise }}$} & \multicolumn{5}{|c|}{ Primary productivity $\left(\mathrm{mg} \mathrm{C} \mathrm{m}^{-2}\right.$ day $\left.^{-1}\right)$} & \multicolumn{5}{|c|}{ Bacterial productivity $\left(\mathrm{mg} \mathrm{C} \mathrm{m}^{-2}\right.$ day $\left.^{-1}\right)$} \\
\hline & 94 & $96-1$ & $96-2$ & $97-1$ & $97-2$ & 94 & $96-1$ & $96-2$ & $97-1$ & $97-2$ \\
\hline 1 & 106 & 535.27 & 464.23 & 88.54 & 95.24 & 89.6 & 259.74 & 381.58 & 78.54 & 66.87 \\
\hline 2 & 99.23 & 495.38 & 1896.3 & 98.27 & 115.24 & 65.1 & 315.47 & 218.88 & 75.27 & 72.58 \\
\hline 3 & 63.58 & 615.23 & 516.8 & 96.54 & 121.35 & 64.3 & 339.24 & 305.73 & 60.64 & 77.69 \\
\hline 4 & 96.05 & 399.24 & 359.35 & 125.33 & 122.58 & 58.85 & 345.87 & 399.95 & 61.24 & 68.58 \\
\hline
\end{tabular}


outcropped to the surface layer by wind stress-driven upwelling (Dickey and Nelson, 1996; Dickey et al., 1998b; McGillicuddy et al., 1998) due to the effects of the storm. However, no outcropping was observed in the study area. Both the inventories of POC and PN as well as the POC/PN ratios showed dramatic differences after the typhoon period. During non-typhoon periods, the study area was characterized by low inventories of POC and PN. In addition, the molar ratios of $\mathrm{POC} / \mathrm{PN}(8.31 \pm 1.06)$ were constant and very close to the Redfield ratios over different sampling stations, indicating that most of the POC and PN were biogenic. Right after the typhoon period, however, higher POC/PN ratios were found at some stations, which suggests that land plant-derived detritus with high POC/PN ratios had entered the study area due to storm runoff.

While the phenomena described above plus the resuspension of bottom sediments may well have taken place, it is clear, however, that neither wind mixing nor terrestrial inputs could have generated the lower temperature yet higher salinity water near the bottom after the typhoon. Some horizontal advection of cool and salty water, which could only have come from off the continental shelf, must have taken place. Higher terrestrial inputs of nitrate-laden river water (Hung et al., 2000) indeed caused the surface nitrate concentrations to increase after the typhoon (Fig. 2d, 96-2), but the effect was confined to the surface layer. Because this surface layer was very fresh and very light, it could not have sunk to the bottom and therefore account for the even higher nitrate concentrations found there. In fact, although there were no indications of upwelling away from shore, there was clear proof of upwelling near the coast after the typhoon (Fig. 2, station 1, 96-1, 962). The buoyancy effect (Hill, 1998; Yanagi et al., 2001) is the most logical explanation for this coastal upwelling.

Although the nearby Tanshui River, situated in the Taipei area, has only a moderately sized drainage area of $2726 \mathrm{~km}^{2}$, its annual outflow is appreciable, at about $7 \times 10^{9} \mathrm{~m}^{3}$, ranking it second highest in terms of outflow in Taiwan. Such a large outflow is a result of the high rainfall of $3000 \mathrm{~mm} \mathrm{year}^{-1}$, which is almost four times the world average of $800 \mathrm{~mm}$ year $^{-1}$. The temporal distribution of rainfall, and hence river outflow, however, is very uneven. As proof of this, the outflow $\left(M_{\mathrm{R}}\right)$ near Taipei during the last 10 days of July 1996 was $183 \mathrm{~cm}\left(\mathrm{~m}^{3} \mathrm{~s}^{-1}\right)$ and this included portions of the rains brought in by typhoon Herb. The outflow increased three-fold to $696 \mathrm{~cm}$ or $6 \times 10^{8} \mathrm{t}^{3}$ in the first 10 days of August after the typhoon. By contrast, in the last 10 days of July 1994, a mere $33 \mathrm{~cm}$ was registered as compared to $386 \mathrm{~cm}$ in the next ten-day period. The last 10 days of July in 1997 had a river outflow of $48 \mathrm{~cm}$, but only $12 \mathrm{~cm}$ in the first 10 days of August (Water Resources Agency; http://www.wra.gov.tw). Salinity data indicate that the depth-integrated $(0-40 \mathrm{~m})$ salinity in the
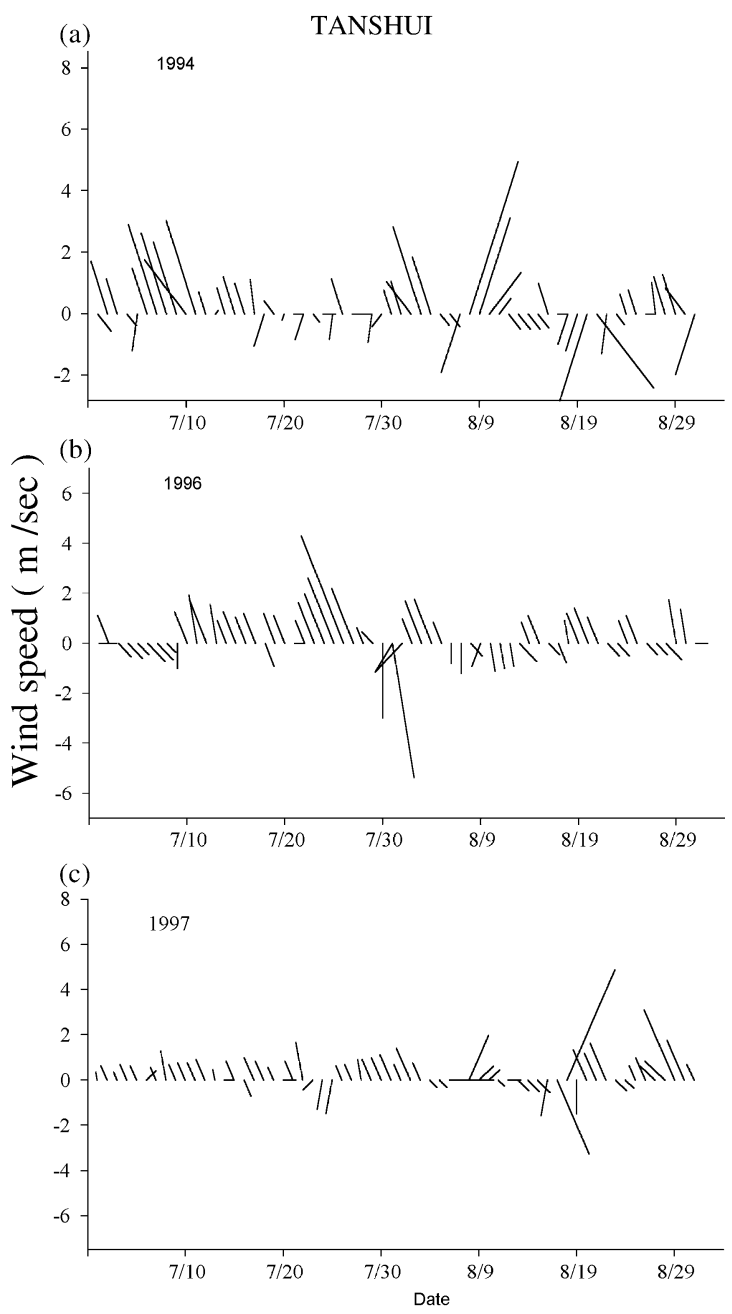

Fig. 3. Wind patterns at the Tanshui River month during July and August in (a) 1994, (b) 1996, and (c) 1997. 
vicinity of stations 1 and 2 decreased from a background value of about $33.55\left(S_{\mathrm{i}}\right)$ to $33.34\left(S_{\mathrm{f}}\right)$ by the runoff in the first 10 days of August 1996, right after typhoon Herb. Simple mass-balance calculations for water and salt can be made based on the approach recommended by the Land-Ocean Interactions in the Coastal Zone project (Gordon et al., 1996; David et al., 2000), as follows:

$M_{\mathrm{i}}+M_{\mathrm{R}}=M_{\mathrm{f}}$

$M_{\mathrm{i}} S_{\mathrm{i}}=M_{\mathrm{f}} S_{\mathrm{f}}$

where $M_{\mathrm{i}}$ and $M_{\mathrm{f}}$ are the masses of the 40-m-thick surface seawater in the affected area before and after the influence of typhoon Herb. Solving the above two equations results in $M_{\mathrm{i}}=9.53 \times 10^{10} \mathrm{t}$ and $M_{\mathrm{f}}=9.59 \times 10^{10}$ t. Further, the mass-balance for nutrients can be represented as follows:

$U=N_{\mathrm{f}} M_{\mathrm{f}}-N_{\mathrm{i}} M_{\mathrm{i}}-N_{\mathrm{R}} M_{\mathrm{R}}$

where $U$ is the amount of nutrient upwelled from the deep and $N_{\mathrm{i}}\left(0.9 \mu \mathrm{mol} \mathrm{kg}{ }^{-1}\right)$ and $N_{\mathrm{f}}(2.2 \mu \mathrm{mol}$ $\mathrm{kg}^{-1}$ ) are the average nutrient concentrations for surface seawater before and after typhoon Herb. The runoff during this period has a nitrate concentration of $89 \mu \mathrm{mol} \mathrm{kg}{ }^{-1}$ (Water Resources Agency; http://www.wra.gov.tw). Solving for Eq. (3) results in $7.2 \times 10^{7} \mathrm{~mol}$ of nitrate upwelled to the vicinities of stations 1 and 2 above a depth of $40 \mathrm{~m}$. It is interesting to note that the nitrate input due to upwelling is larger than the riverine input in this particular case. If upwelling caused by typhoons are also typical in other
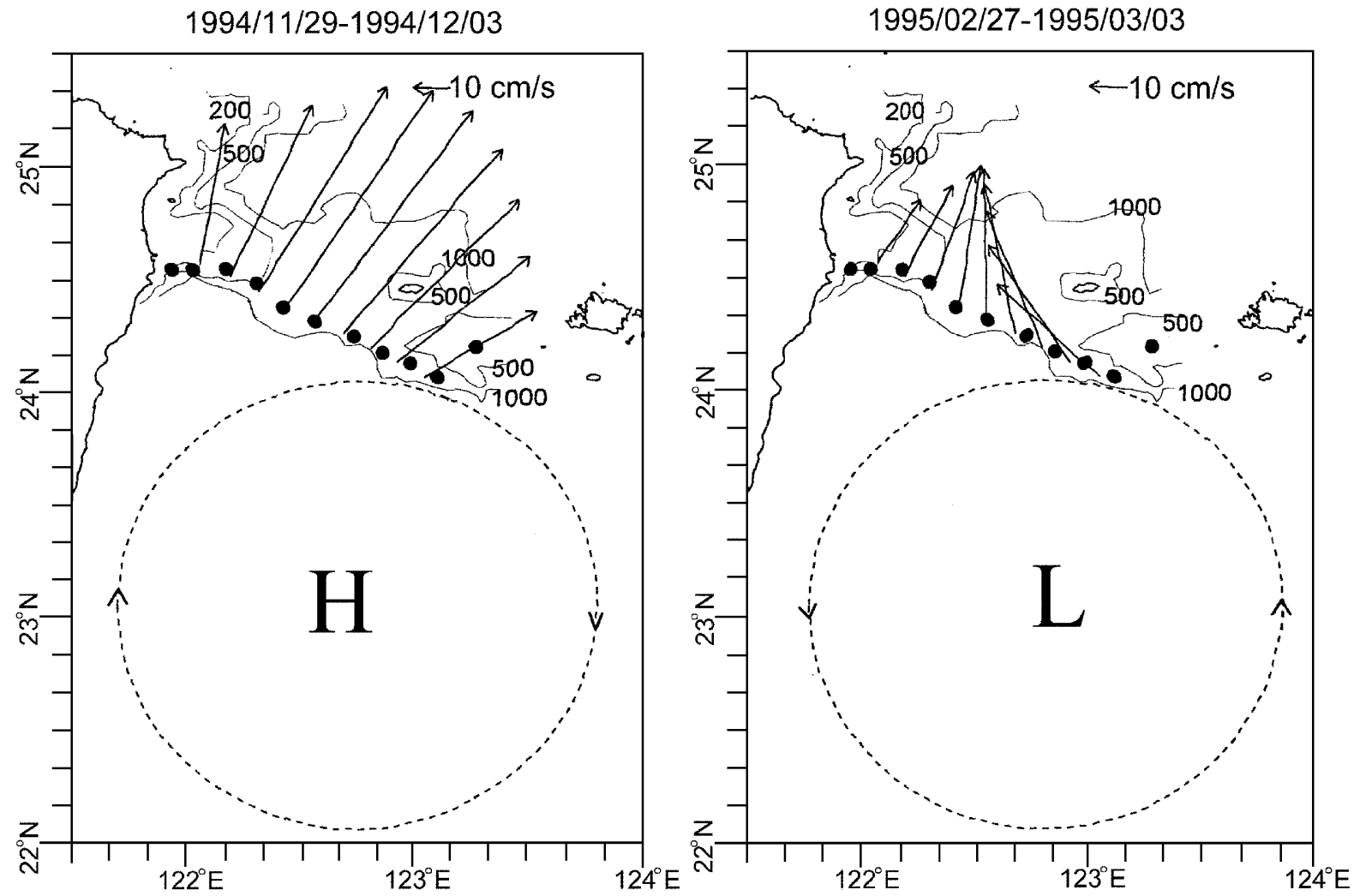

Fig. 4. Schematic plots for the suggestion of interaction between the Kuroshio and anticyclonic (left panel) and cyclonic (right panel) eddies east of Taiwan. Two time frames of the 5-day, upper $400 \mathrm{~m}$-vertical-averaged current vectors during the periods from November 29 , 1994 to December 12, 1994 (left) and from February 27, 1995 to March 03, 1995 (right) are also shown (redrawn from Yang, 1999). 
coastal regions, the three to four typhoons that pass Taiwan on an average year could contribute significantly to coastal productivities.

Of interest too is that essentially no water colder than $24{ }^{\circ} \mathrm{C}$ was observed above $70 \mathrm{~m}$ at the four stations in 1994 and 1997, but water colder than $21^{\circ} \mathrm{C}$ was observed during 96-2 (Fig. 2a). Also, salinity in the subsurface layer in the normal years was generally at least 0.15 lower than that in 96-2 (Fig. 2b). These findings strongly indicate that intrusion of the colder and more saline Kuroshio subsurface waters was much less significant during the period when no typhoon occurred. The salinity of surface water, however, was clearly higher when there was no typhoon, but this was apparently due to lower rainfall and river runoff.

It is important to point out that the deepening of the temperature, salinity and $\sigma_{\mathrm{t}}$ contours closer to the coast is highly indicative of downwelling during normal years (Fig. 2a, b and c; 94, 97-1, 97-2) at periods when the southwest monsoon winds prevail (Fig. 3a, c) and the prevailing currents flow northward (Shaw, 1992). On the other hand, the shoaling contours between stations 2 and 1 (Fig. 2a-c; 96-1 and 96-2) suggest coastal upwelling a few days after the typhoon even when prevailing monsoon winds might be expected to favor downwelling. Mass-balance calculations indicate that the larger buoyancy forcing caused by a larger fresh water input to the continental shelf should result in a larger upwelling of subsurface waters from offshore (Hill, 1998; Chen, 2000). The colder, saltier, denser and more nutrient-rich subsurface waters found during 96-2 imply that the upwelling phenomena were more pronounced during 96-2 than during 96-1, perhaps on account of larger buoyancy effect during 96-2. Apparently, the buoyancy effect played a larger, albeit maybe only temporary, role than did the prevailing winds after the typhoon. Since waters colder than $21{ }^{\circ} \mathrm{C}$ but with a salinity close to 34.4 cannot be found in the Taiwan Strait or the adjacent East China Sea continental shelf in summer, there is every indication to assume that they probably originated from the subsurface Kuroshio water at about $100 \mathrm{~m}$ (Chen, 1996).

The other effects of a typhoon may come from its winds. Certainly, episodic events, like cyclones, generate vertical mixing. In addition, they may even force the axis of the Kuroshio to move shoreward, similar to what an impinging eddy does to a warm current. For instance, Yang et al. (1999) reported that an approaching anticyclonic eddy would result in a larger mass transport of the Kuroshio, and conversely, a reduction in mass transport as a cyclonic eddy arrives. This trend is illustrated in Fig. 4.

It is believed that when an anticyclonic eddy with a diameter of say $200 \mathrm{~km}$ is incoming, the northward flowing Kuroshio is also enhanced because of the northward flowing water on the western part of the eddy. The observed current vectors substantiate this conclusion. However, before the eastern part of an eddy with its southward flowing water can impede the northward flow of the Kuroshio, the eddy dissipates

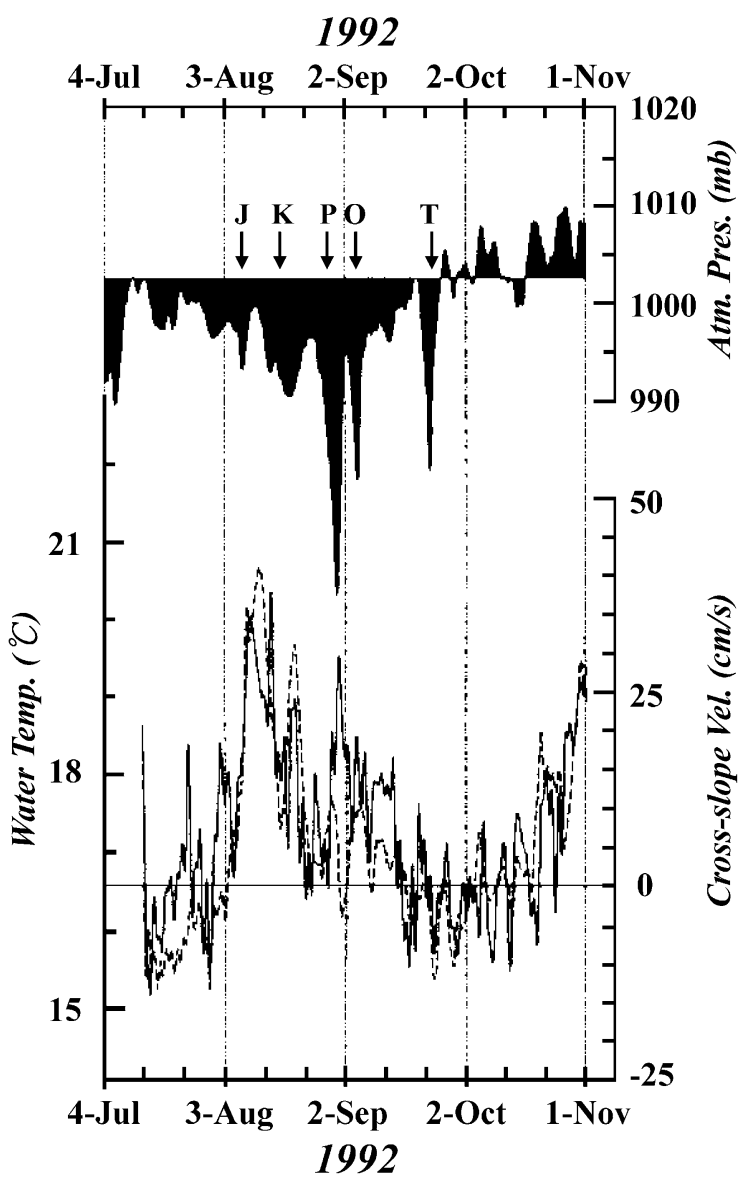

Fig. 5. Time series of the atmospheric pressure, as well as the shelfward current (solid line) and temperature (dashed line) recorded at station C northeast of Taiwan in 1992. J, K, P, O and $\mathrm{T}$ denote typhoons Janis, Kent, Pally, Omar and Ted. 

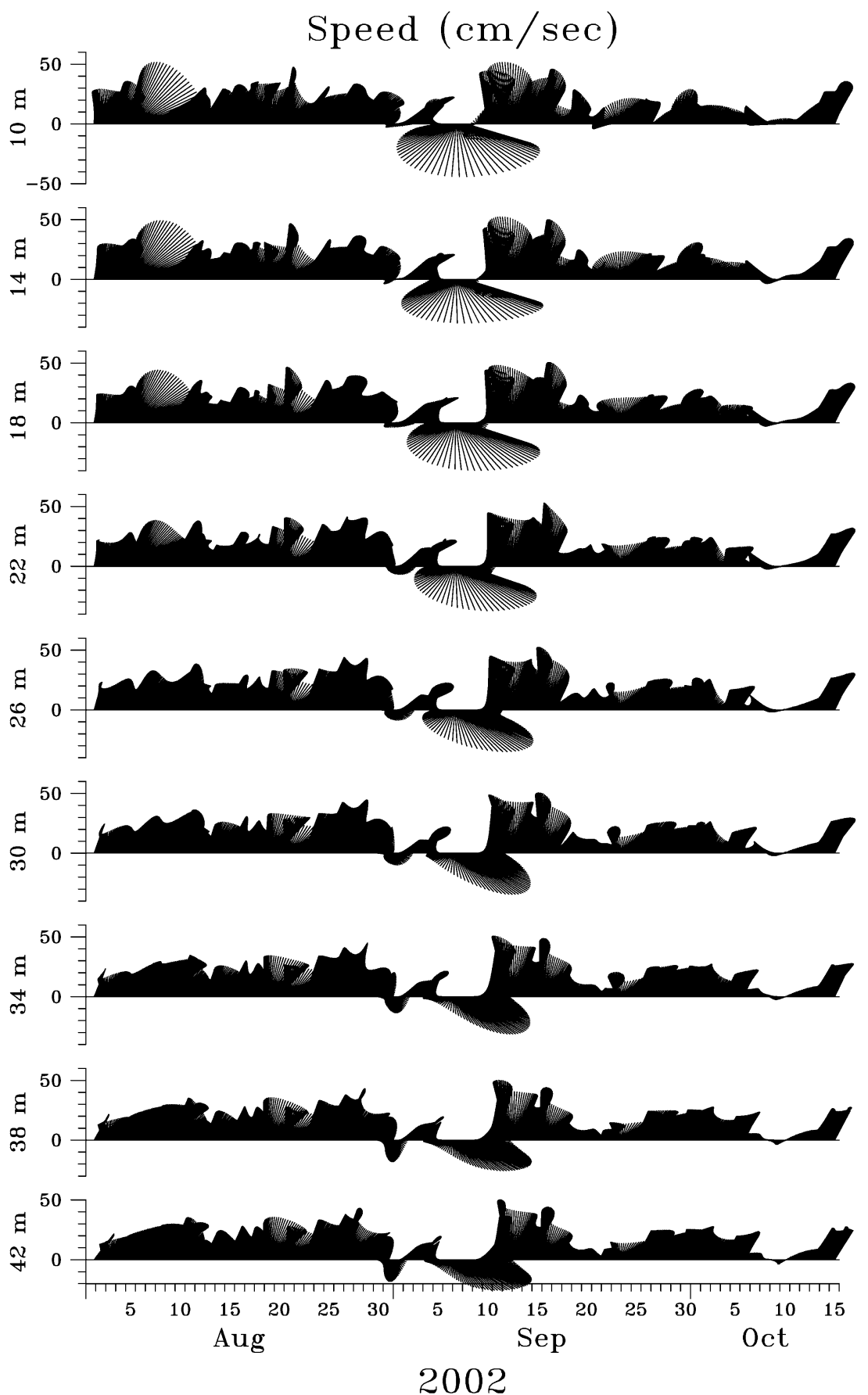

Fig. 6. Time series of current speeds collected by a bottom-mounted ADCP near station 4 of the study area in 2002. 


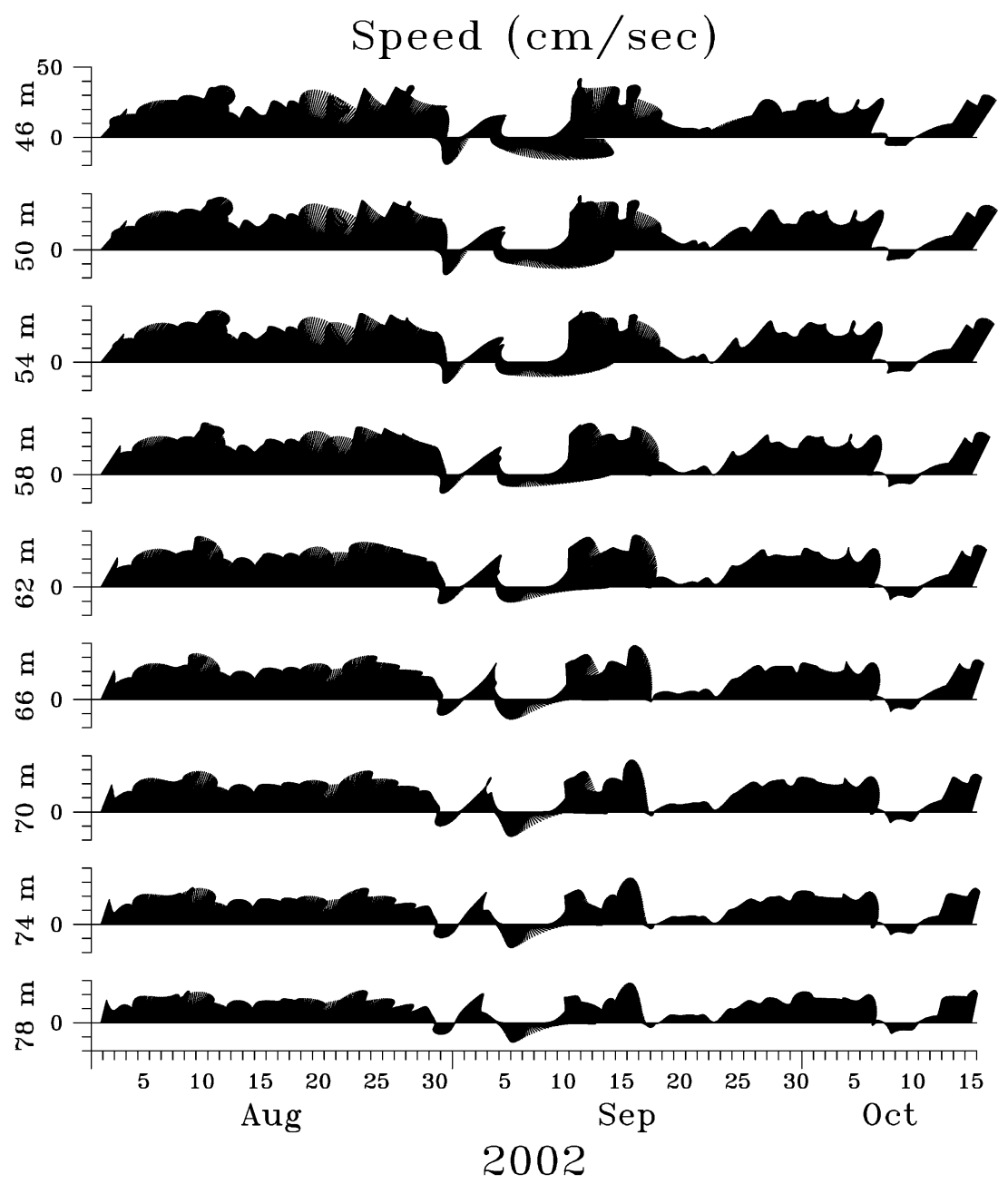

Fig. 6 (continued).

when it hits Taiwan and its shelves (Fig. 4a). On the other hand, when a cyclonic eddy moves in, its southward flowing western portion is able to impede the northward flow of the Kuroshio, thus diminishing the northward current vector (Fig. 4b). At that point, the observed current vectors turn toward the shelf because of the westward flowing water in the northern part of the cyclonic eddy. Again, the eddy dissipates before its northward flowing eastern portion is able to enhance the Kuroshio.

It seems that the above theory also applies to a typhoon, such as typhoon Herb. For instance, Shuto (2001) reported that the current axis of the Kuroshio shifted $55.5 \mathrm{~km}$ closer to Japan and that its velocity decreased by $1.08 \mathrm{~m} \mathrm{~s}^{-1}$ after a typhoon had passed. On the other hand, currents accelerated by $0.5 \mathrm{~m} \mathrm{~s}^{-1}$ on the coastal side. In their temperature and salinity cross-sections, furthermore, the inclination of the isoclines forming the permanent thermocline and halocline decreased. Finally, the maximum temperature and salinity on the coastal side became $9{ }^{\circ} \mathrm{C}$ and 0.5 higher, respectively, after the passage of the typhoon. These are indications that remnants of the South China Sea (SCS) water, which occupies the western portion of the Kuroshio and is generally lower in temperature and salinity at the same density surface (Chen and Wang, 1998), was pushed toward shore. 
It is unfortunate that we do not have current meter data near our study area between 1994 and 1997. There were, however, such data in 1992. Fig. 5 shows the current meter data collected at $109 \mathrm{~m}$ in water depth at station $\mathrm{C}$ near the shelf break (Fig. 1) northeast of our study area. The cross-shelf, onshore component surged after typhoons Janis, Kent, Pally, Omar and Ted passed on, respectively, August 7, August 17, August 29, September 4 and September 23, 1992. All of them could be identified by depressions in the atmospheric pressure and decreases in water temperature. The most notable example is after the powerful typhoon Pally, which clearly resulted in onshore transport of cold, and presumably nutrient-rich (Chen, 1996), subsurface Kuroshio water toward our study area at a speed as high as $30 \mathrm{~m} \mathrm{~s}^{-1}$ (Chuang and Liang, 1994). Another example is given in Fig. 6, which shows the current speed collected by a bottom mounted ADCP near station 4 of our study area. It is clearly seen that after typhoons Rusa and Sinlaku passed on, respectively, August 30 and September 7, 2002, the currents reversed direction from northward to southward. Current vectors from surface to bottom also support the observations made in 1992 that typhoons helped push subsurface waters towards our study area.

Since the subsurface SCS waters are richer in nutrients than the West Philippine Sea waters which form the eastern portion of the Kuroshio, pushing the SCS component toward shore could reasonably suggest a higher nutrient input to the shelves as a result of cross-shelf upwelling. Though this requires further investigation, the effect would certainly help in the nurturing of the shelf waters.

\section{Conclusions}

Evidence is provided to show that prevailing SW monsoon winds induce coastal downwelling off the northeastern corner of Taiwan in summer. Right after the passage of typhoon Herb in 1996, however, coastal downwelling changed to upwelling due to buoyancy forcing caused by the discharge of fresh water from land. The upwelled water, with lower temperature, but higher salinity, density and nitrate concentration probably originated in the Kuroshio subsurface waters, which were likely pushed toward shore by the typhoon.

\section{Acknowledgements}

Support for this research was provided by the National Science Council, Taiwan, ROC (NSC 912611-M-110-013). S.J. Kao and G.C. Gong contributed to part of data used in the present paper. K. Shuto, J. Wang, C.S. Chern and two anonymous reviewers provided valuable comments.

\section{References}

Biscaye, P.E., Flagg, C.N., Falkowski, P.G., 1994. The shelf-edge exchanges processes experiment, SEEP-II: an introduction to hypotheses, results and conclusions. Deep-Sea Research 41 (2/3), $231-252$.

Chang, J., Chung, C.C., Gong, G.C., 1996. Influences of cyclones on chlorophyll-a concentration and Synechococcus abundance in a subtropical western Pacific coastal ecosystem. Marine Ecology. Progress Series 140, 199-205.

Chen, C.T.A., 1996. The Kuroshio intermediate water is the major source of nutrients on the East China Sea continental shelf. Oceanologica Acta 19, 523-527.

Chen, C.T.A., 2000. The Three Gorges Dam: reducing the upwelling and thus productivity in the East China Sea. Geophysical Research Letters 27, 381-383.

Chen, C.T.A., Wang, S.L., 1998. Influence of intermediate water in the western Okinawa trough by the outflow from the South China Sea. Journal of Geophysical Research 103, 12683-12688.

Chen, C.T.A., Holligan, P., Hong, H.S., Iseki, K., Krishnaswami, S., Wollast, R., Yoder, J., 1994. Land-ocean interactions in the coastal zone. JGOFS Report 15 (SCOR, 20 pp.).

Chen, C.T.A., Ruo, R., Pai, S.C., Liu, C.T., Wong, G.T.F., 1995. Exchange of water masses between the East China Sea and the Kuroshio off northeastern Taiwan. Continental Shelf Research $15,19-39$.

Chen, C.T.A., Lin, C.M., Huang, B.T., Chang, L.F., 1996. The stoichiometry of carbon, hydrogen, nitrogen, sulfur and oxygen in the particular matter of the western North Pacific marginal seas. Marine Chemistry 54, 179-190.

Chen, C.T.A., Liu, K.K., MacDonald, R., 2003. Continental margin exchanges. In: Fasham, M.J.R. (Ed.), Ocean Biogeochemistry: A JGOFS Synthesis. Springer, Berlin, pp. 53-97.

Chew, F., Drennan, K.L., Demoran, W.J., 1962. Drift-bottle return in the wake of Hurricane Carla, 1961. Journal of Geophysical Research 67, 2773-2776.

Chuang, W.S., Liang, W.D., 1994. Seasonal variability of intrusion of the Kuroshio water across the continental shelf northeast of Taiwan. Journal of Oceanography 50, 531-542.

David, L.T., San Diego-McGlone, M.L., Crossland, C.J., Smith, S.V., 2000. LOICZ Biogeochemical Budgeting Procedure: A 
Tutorial Pamphlet, LOICZ, International Project Office. Texel, The Netherlands. 29 pp.

Dickey, T.D., Nelson, N., 1996. In the eye of the storm: Bermuda mooring records hurricane's passage. US-JGOFS Newsletter, 5-6 (September).

Dickey, T.D., Chang, G.C., Agrawal, Y.C., Williams III, A.J., Hill, P.S., 1998a. Sediment resuspension in the wakes of Hurricane Edouard and Hortense. Geophysical Research Letters 25, $3533-3536$.

Dickey, T.D., Frye, D., McNeil, J., Manov, D., Nelson, N., Sigurdson, D., Jannasch, H., Siegel, D., Michaels, A., Johnson, R., 1998b. Upper ocean temperature response to Hurricane Felix as measured by the Bermuda Testbed Mooring. Monthly Weather Review 126, 1195-1201.

Furnas, M.J., 1989. Cyclonic disturbance and a phytoplankton bloom in a tropical shelf system. In: Okaichi, T., Anderson, D.M., Nemoto, T. (Eds.), Red Tides Biology, Environmental Science, and Toxicology. Elsevier, New York, pp. 273-276.

Gilbes, F., Armstrong, R.A., Webb, R.M.T., Müller-Karger, F.E., 2001. SeaWiFS helps assess hurricane impact on phytoplankton in Caribbean Sea. EOS, Transactions, American Geophysical Union, 82, p. 529 and 533.

Gong, G.C., Shyu, C.Z., Shiu, W.H., Liu, K.K., 1992. Temperature fluctuation of the cold eddy off northeastern Taiwan: JuneDecember, 1990. Acta Oceanographica Taiwanica 28, 118-127.

Gong, G.C., Chen, Y.L.L., Liu, K.K., 1996. Chemical hydrography and chlorophyll- $a$ distribution in the East China Sea in summer: implications in nutrient dynamics. Continental Shelf Research 16 (12), $1561-1590$.

Gordon Jr., D.C., Boudreau, P.R., Mann, K.H., Ong, J.E., Silvert, W.L., Smith, S.V., Wattayakorn, G., Wulff, F., Yanagi, T., 1996. LOICZ biogeochemical modelling guidelines. LOICZ Reports and Studies, vol. 5. Texel, The Netherlands. 96 pp.

Gu, H.K., 1991. Marine Chemistry of the Bohai Sea, the Yellow Sea and the East China Sea. Science Press, Beijing, China. 500 pp. In Chinese.

Hall, J.A., Smith, S.V., Boudreau, P., 1996. Report on the International Workshop on continental shelf fluxes of carbon, nitrogen and phosphorus. LOICZ Reports and Studies, vol. 9. Texel, The Netherlands. 50 pp.

Hill, A.E., 1998. Buoyancy effects in the coastal and shelf seas. In: Brink, K.H., Robinson, A.R. (Eds.), The Sea, vol. 10. Wiley, New York, pp. 21-62.

Hung, J.J., Fang, T.H., Kuo, F., Chen, C.P., 2000. Tanshui River Estuary. In: Dupra, V., Smith, S.V., Crossland, J.I.M., Crossland, C.J. (Eds.), Estuarine Systems of the East Asia Region: Carbon, Nitrogen and Phosphorus Fluxes. LOICZ Reports and
Studies, vol. 16. Netherlands Institute for Sea Research, Texel, pp. $62-67$.

Jickells, T.D., 1998. Nutrient biogeochemistry of the coastal zone. Science 281, 217-222.

Liu, K.K., Atkinsion, L., Chen, C.T.A., Gao, S., Hall, J., MacDonald, R.W., Talaue McManus, L., Quinones, R., 2000. Exploring continental margin carbon fluxes on a global scale, EOS, 81, 641-642, 644 .

McGillicuddy, D.J., Robinson, A.R., Siegel, D.A., Jannasch, H.W., Johnson, R., Dickey, T.D., McNeil, J.D., Michaels, A.F., Knap, A.H., 1998. New evidence for the impact of mesoscale eddies on biogeochemical cycling in the Sargasso Sea. Nature 394, $263-266$.

McLeish, W., Hansen, D.V., Proni, J.R., 1997. Coastal currents induced by Hurricane Andrew. Florida Scientist 60, 254-264.

Murray, S.P., 1970. Bottom currents near the coast during Hurricane Camille. Journal of Geophysical Research 75, 4579-4582.

Ritzrau, W., Graf, G., 1992. Increase of microbial biomass in the benthic turbidity zone of Kiel Bight after resuspension by a storm event. Limnology and Oceanography 37 (5), $1081-1086$.

Shaw, P., 1992. Shelf circulation off the southeast coast of China. Review of Aquatic Science 6 (1), 1-28.

Shiah, F.K., Chung, S.W., Kao, S.J., Gong, G.C., Liu, K.K., 2000. Biological and hydrographical responses to tropical cyclones (typhoons) in the continental shelf of the Taiwan Strait. Continental Shelf Research 20, 2029-2044.

Shuto, K., 2001. Changes of Kuroshio caused by Typhoon 6804 . Oceanography in Japan 10, 137-145.

Smith, N.P., 1982. Response of Florida Atlantic shelf waters to Hurricane David. Journal of Geophysical Research 87, 2007-2016.

Wang, Y.H., 1991. Marine Atlas of Bohai Sea, Yellow Sea, East China Sea. Chemistry. China Ocean Press, Beijing. 257 pp.

Wong, G.T.F., Chao, S.Y., Li, Y.H., Shiah, F.K., 2000. The Kuroshio Edge Exchange Processes (KEEP) - an introduction to hypotheses and highlights. Continental Shelf Research 20, 335-347.

Yanagi, T., Sachoemar, S.I., Takao, T., Fujiwara, S., 2001. Seasonal variation of stratification in the Gulf of Thailand. Journal of Oceanography 57, 461-470.

Yang, Y., 1999. Low-frequency variability of the Taiwan Current (Kuroshio) volume transport and its long-term monitoring. $\mathrm{PhD}$ dissertation, National Taiwan University. 112 pp.

Yang, Y., Liu, C.T., Hu, J.H., Koga, M., 1999. Taiwan Current (Kuroshio) and impinging eddies. Journal of Oceanography 55, 609-617. 